\title{
Strategic Formulation Analysis to Build a New Mechanical Testing Laboratory in Indonesia
}

\author{
Subhan ${ }^{1}$, Muhamad Elon ${ }^{2}$, Farid Nur Iman ${ }^{3}$, Salmen Ginting 4 , \\ Lily Lestari Christalina ${ }^{5}$, Rhian Indradewa ${ }^{6}$, Edi Hamdi ${ }^{7}$, \\ Tantri Yanuar Rahmat $\operatorname{Syah}^{8}$
}

1,2,3,4,5,6,7,8 Department Management, Faculty Economic and Business, Esa Unggul University, Jakarta - Indonesia

\author{
Corresponding Author: Subhan
}

DOI: https://doi.org/10.52403/ijrr.20220239

\begin{abstract}
PT. Premium Testing Lab is startup company that is established to provide solution for mechanical testing especially for manufacturing industry. Mechanical testing is carried out to ensure the material or product is safe, strong, durable, and also certified with KAN ISO 17025. Before starting a business, it is very important to analyze both internal and external factor as well as carry out strategy formulation. A qualitative method was conducted through questionaries to competitors, customers and experts. This paper provides information how to use several tools for strategy formulation that can be applied to any startup company in order to be more competitive and sustainable.
\end{abstract}

Keywords: Mechanical testing, laboratory, internal and external analysis, strategy formulation, startup.

\section{INTRODUCTION}

Mechanical testing is required for almost all industry segments, such as automotive, plastics, rubber, food, composites, packaging, textile, steel, and medical products industries. Mechanical testing is carried out to ensure that the materials or products produced are safe, strong, durable, and also certified to ISO 17025. Every mechanical test carried out always refers to a testing standard, both local standards (SNI), international standards as well as customer standards.
The number of large and mediumscale manufacturing industries according to data from BPS Jawa Barat in 2018 (the book of Statistics for Large and Medium Industries West Java 2018) amounts to around 9,470 companies, where this number experienced a decline in growth of $6.64 \%$ from the previous year. From these number, the industries relevant to our mechanical testing are 5,565 companies. Meanwhile, the number of mechanical test labs in the West Java region is still small compared to the existing manufacturing industry, and they only serve certain industrial segments, and most of them are government testing house. Government-owned testing house generally take 30-40 days to complete testing from samples submitted by customers until the certificate is received, while customers are pressed for time by their clients to attach test results certificates as soon as possible indicating the quality of their products.

PT Premium Testing Lab (PTL) is a startup company that came to provide solutions for mechanical testing especially for manufacturing industries. PTL provides 2 test packages related to the testing time until the certificate is issued. The first is the Premium package and the second is the Premium Express package. The premium plan offers 14 days of testing time from the time the test sample is received until the certificate is issued. While the Premium 
Express package offers 7 days to help some customers to get their testing results faster.

\section{MATERIALS AND METHODS Identify Problems and Opportunities}

In the early stages, the PTL team identified problems and opportunities first, this identification is done through analysis of customer jobs, customer pains and customer gains. Customer jobs are what our customer are trying to accomplish in their work, customer pains describe poor outcomes, risk, and obstacles regarding such work, while customer gain describes result which customer is seeking or wants to achieve (Osterwalder, 2014). PTL team also determined value proposition canvas, this is important because it is at the core of everything that focuses on organizational values, sharpens the way the organization works by focusing on activities to serve customers profitably (Barnes, C., Blake, H., \& Pinder, 2009; Clark et al., 2012). After all, Value Proposition Canvas will help create value for customers, helping companies design products and services that customers wish to (Osterwalder, 2014)

\section{a. Vision and Mission}

Vision and mission are a very important part in a company. Vision and mission can be used as benchmarks to achieve the success and progress of a company. Vision tells us about the future and suggests how we should change, where we will get and how we will be in future. Vision acts as motivation; it offers us new possibilities about how we can succeed. (Papulova, 2014). Mission statement is rated as second most used tool specifically because they see it is as a useful substance in organizational integration which gets everybody focused on goals and working together to pull the same direction (Akeem \& Edwin, 2016)

\section{b. External Factor Analysis}

External Factor Analysis is a process used by strategic planners to monitor opportunities and threats to the company in carrying out its business processes. The consumer's need to get fast and accurate test results is an opportunity to enter the test laboratory business. In the external analysis, the Porter Five Forces model and PEST analysis are used. Porter's analysis is used to determine the environmental conditions around the business from five strengths, namely product development potential, substitute products, supplier strength, buyer power, and competition between similar companies.(Candra, 2013). PEST analysis consists of political, economic, social and technological. The analysis examines the impact of each of the factors on the business. The results can be used to take advantage of opportunities and to make contingency plans for threats (Koumparoulis, 2013).

\section{c. Internal Factor Analysis}

In order to build a competitive advantage in company, requires activities that are supported by various internal factors to be able to find the company's strengths and weaknesses. Based on business solutions, this activity includes analysis of demand, competition, resources and capabilities, determining strengths and weaknesses, and determining the company's competitive advantage (Setiyawati et al., 2021). According to Grant (2010), to survive and thrive in an industry, a company must meet two criteria: first, it must be able to meet what customers want to buy and second, it must be able to survive in the competition.

\section{d. Strategic Planning}

Strategic planning is an important thing that must be done to determine which strategy should be taken by the company based on the vision and mission, the results of internal and external analysis of a company. One of the tools used to determine alternative strategies is the SWOT matrix. SWOT analysis is important for both organizations and employees. It helps one in making an assessment based on understanding of strengths, weaknesses, 
opportunities and threats (Dr. Alka Jain, 2015).

\section{DISCUSSION \\ Identify Problems and Opportunities}

\section{a. Customer Jobs}

Manufacturing Industry has been doing mechanical testing to measure the strength of the products or materials they use to create a product and meet the demands of their clients. Customers usually come directly to the Test Lab to discuss the testing process and register their company to carry out testing at the testing house. After that, they have to make full payment followed by sample delivery. After the test carried out, the results will be checked which will then be signed by lab manager. Furthermore, a certification of test results will be issued and will be submitted to the customer. The purpose of this test is to control the quality of their products, create new innovations from the product side and convince their clients by attaching a certificate of good test results.

\section{b. Customer Pains}

Government-owned testing house generally take 30-40 days to complete testing from samples submitted by customers until the certificate is received, while customers are pressed for time by their clients to attach test results certificates as soon as possible to indicating the quality of their products. Even when applying for registration, customers have to queue for a long time and the response they get is not really fast. In addition, the machines used in government-owned mechanical testing house are dominated by old machines or machines whose accuracy level is so low that makes customers complain about the test results their obtained are less accurate. Customers also complain about the flexibility of testing in government-owned testing house.

\section{c. Customer Gains}

Some of these points are customer gains our group could identify. These include a minimum of 1-year warranty for all products, easy to assemble and disassemble. Containers should be easily placed anywhere, even when delivered to locations with small access roads. Next, the unique designs according to consumer desires. Then, they want a cool temperature and good air circulation in containers, containers with alternative electricity, especially for business actors who want to place their containers in locations with difficult access to electricity, can buy containers with an instalment system.

\section{Business Solutions a. Pains Reliever}

A test center is needed that can provide fast and accurate test services (the fact test can be done in 5 minutes for 1 specimen). This speed parameter is one thing that customers in this business want. To produce accurate test results, a testing house is needed that uses premium testing machines. Customers also want to be able to see firsthand the testing process and around international standards such as ISO and ASTM, for that test centers must be more flexible in this regard. We use this strategy to overcome customer pain.

\section{b. Gains Creator}

PTL offers Pre Consultation, Pre Test and Pick Up to customers which can be an added value from the services we offer compared to our competitors. To support a fast service process, we developed the PTL View application that our competitors do not have with several advantages such as being able to track the testing process to downloading test results in the form of reports or test images/videos.

The results of the identification of problems, opportunities and business solutions are concluded in the value proposition canvas as shown in Figure 1 below. 


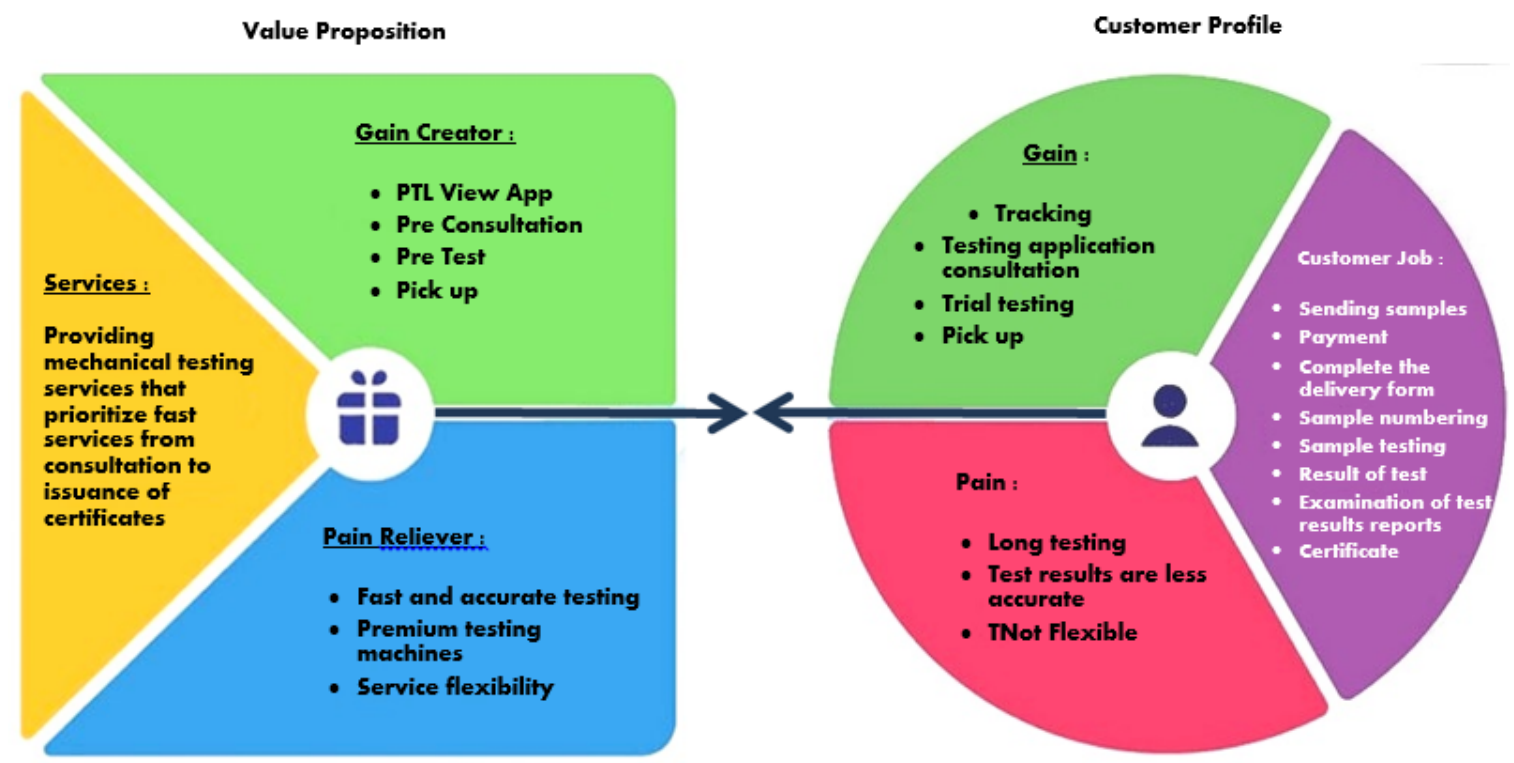

Figure 1. PTL Value Proportion Canvas Source: Author, 2021

\section{External Factor Analysis a. Porter Five Forces}

Table 1. Measurement Results of Porter's Five Forces Matrix Forces

\begin{tabular}{|c|c|c|c|}
\hline Forces & Weight & Index & Value \\
\hline \multicolumn{4}{|l|}{ Threat of New Entrants } \\
\hline Capital requirements & 0.3 & 1 & 0.3 \\
\hline Regulation & 0.4 & 3 & 1.2 \\
\hline Variation of Test & 0.3 & 2 & 0.6 \\
\hline Total Score & & & 2.1 \\
\hline
\end{tabular}

Competitive Rivalry

Number of Similar Competitors

\begin{tabular}{|c|c|c|c|}
\hline Number of Similar Competitors & 0.2 & 3 & 0.6 \\
\hline Service Quality & 0.3 & 2 & 0.6 \\
\hline Testing Machine Quality & 0.3 & 2 & 0.6 \\
\hline Test price per specimen & 0.2 & 3 & 0.6 \\
\hline Total Score & & & 2.4 \\
\hline
\end{tabular}

\begin{tabular}{|l|c|c|c|}
\hline \multicolumn{1}{|c|}{ Total Score } & \multicolumn{2}{l|}{} & $\mathbf{2 . 4}$ \\
\hline Competitive Rivalry & 0.8 & 1 & 0.8 \\
\hline Machine investment & 0.2 & 1 & 0.2 \\
\hline Future technology & & & $\mathbf{1}$ \\
\hline \multicolumn{2}{|c|}{ Total Score } & & \\
\hline Bargaining Power of Suppliers & 0.4 & 1 & 0.4 \\
\hline $\begin{array}{l}\text { Number of mechanical testing } \\
\text { machine suppliers }\end{array}$ & 0.6 & 3 & 1.8 \\
\hline Relationship with suppliers & & & $\mathbf{2 . 2}$ \\
\hline Total Score & 0.3 & 1 & 0.3 \\
\hline Bargaining Power of Buyers & 0.4 & 2 & 0.8 \\
\hline Number of Customers Total Score & 0.3 & 1 & 0.3 \\
\hline Customer loyalty & & $\mathbf{1 . 4}$ \\
\hline Buyer Switching cost Sotal Average & & & $\mathbf{2 . 0 2}$ \\
\hline \multicolumn{2}{|c|}{}
\end{tabular}

This Strength Analysis can be used to analyze the company's external environment. The five power models that we summarize is shown in table 1. Based on the results of the discussion of the five competitive forces above, it can be seen that the average weighting of the five competitive forces is a total of 2.02. The weight can be concluded that the competitive strength of the container modification industry is moderate.

\section{b. PEST}

PEST analysis analyses the external business environmental factors that include the political, economic, social and technological fields (Ward and Peppard, 2002). PEST is used to assess the market of a business unit / organizational unit. Based on our PEST analysis, we can draw assumptions after conducting our research, as shown in the table 2 .

Based on the results of the weighting of the EFE matrix the number of scores is 3.01. This is above average (2.5). This total score also shows that PTL can respond well to opportunities and threats that come from external factors of the company. If referring to freed David page 81, it is mentioned that as long as it is still above the average value of 2.5 then it is still quite good, and there is still plenty of room to develop considering the highest total score is 4.0. 
Table 2. External Factor Evaluation Matrix of PT Premium Testing Lab

\begin{tabular}{|c|l|c|c|c|}
\hline No. & External Factor & Weight & Rating & $\begin{array}{c}\text { Weight } \\
\text { Score }\end{array}$ \\
\hline & Opportunities & & & \\
\hline $\mathbf{1}$ & Changes or additions of mandatory SNI for certain products & 0,08 & 4 & $\mathbf{0 , 3 2}$ \\
\hline $\mathbf{2}$ & Consumer Protection Act & 0,03 & 3 & $\mathbf{0 , 0 9}$ \\
\hline $\mathbf{3}$ & Recommendations from the ministry of industry for certification of products/materials & 0,1 & 4 & $\mathbf{0 , 4}$ \\
\hline $\mathbf{4}$ & Investment Climate in Indonesia encourages the manufacturing industry to move to Indonesia & 0,05 & 3 & $\mathbf{0 , 1 5}$ \\
& (Copyright Law no. 11 of 2020) & & & \\
\hline $\mathbf{5}$ & Growth of manufacturing industry in Indonesia 0.6 to 3.73\% & 0,12 & 4 & $\mathbf{0 , 4 8}$ \\
\hline $\mathbf{6}$ & Manufacturing companies want to test in private laboratories because they are faster than & 0,09 & 4 & $\mathbf{0 , 3 6}$ \\
\hline $\mathbf{7}$ & government laboratories. & & & \\
\hline $\mathbf{8}$ & There is a need to get accurate and reliable test results & 0,09 & 4 & $\mathbf{0 , 3 6}$ \\
\hline & Threats & 0,07 & 4 & $\mathbf{0 , 2 8}$ \\
\hline $\mathbf{1}$ & Changes in test procedures or parameters on international standards both ISO and ASTM & & \\
\hline $\mathbf{2}$ & Policy changes related to SNI ISO/IEC 17025 "General Requirements of Competence of Testing & 0,05 & 2 & $\mathbf{0 , 1}$ \\
\hline & Laboratories and Calibration Laboratories & 0,04 & 2 & $\mathbf{0 , 0 8}$ \\
\hline $\mathbf{3}$ & Issues related to dynamic labor regulations & 0,05 & 1 & $\mathbf{0 , 0 5}$ \\
\hline $\mathbf{4}$ & Investment Climate Change for West Java region & 0,07 & 2 & $\mathbf{0 , 1 4}$ \\
\hline $\mathbf{5}$ & Bank loan rates rise & 0,06 & 1 & $\mathbf{0 , 0 6}$ \\
\hline $\mathbf{6}$ & High competition with similar business people. & 0,06 & 1 & $\mathbf{0 , 0 6}$ \\
\hline $\mathbf{7}$ & Technological developments that must continue to be upgraded following suppliers. & 0,04 & 2 & $\mathbf{0 , 0 8}$ \\
\hline & Total & 1 & & $\mathbf{3 , 0 1}$ \\
\hline
\end{tabular}

Source: Author, 2021

\section{Internal Factor Analysis}

In building a startup business, internal factor analysis is needed so that the business can run well, be able to win the competition and be sustainable. Internal analysis includes what resources and capabilities the company needs. The results of the analysis at this stage can be seen in
Table 3. below. Demand Analysis is an understanding and concept in a system of customer demand for a product or service in a particular market, while the Analysis of competition is what efforts must be made by the company to survive in the competition. (Grant, 2010)

Table 3. PT PTL Internal Factor Analysis (IFE).

\begin{tabular}{|c|l|c|c|c|}
\hline No. & \multicolumn{1}{|c|}{ Key Internal Factors } & Weight & Rating & $\begin{array}{c}\text { W- } \\
\text { Scored }\end{array}$ \\
\hline & Strengths & & \\
\hline 1 & PTL uses premium grade testing machines made in Germany & 0,08 & 3 & 0,24 \\
\hline 2 & Choosing a strategic location near the Cikarang industrial area & 0,1 & 4 & 0,4 \\
\hline 3 & $\begin{array}{l}\text { PTL will be a pioneer test center that utilizes android applications for tracking } \\
\text { and documentation }\end{array}$ & 0,07 & 3 & 0,21 \\
\hline 4 & $\begin{array}{l}\text { PTL's speed of service, consulting and flexibility is above the competition's } \\
\text { average }\end{array}$ & 0,1 & 4 & 0,4 \\
\hline 5 & $\begin{array}{l}\text { Prices are in accordance with the services provided and the benefits accepted by } \\
\text { consumers }\end{array}$ & 0,06 & 3 & 0,18 \\
\hline 6 & PTL serves mechanical testing of various industrial segments & 0,08 & 4 & 0,32 \\
\hline 7 & Reliable test results & 0,07 & 4 & 0,28 \\
\hline 8 & $\begin{array}{l}\text { PTL has established a relationship with IQI and P3MB to expand its marketing } \\
\text { network }\end{array}$ & 0,06 & 3 & 0,18 \\
\hline 1 & $\begin{array}{l}\text { Weakness } \\
\text { PTL HR is still limited, the number of employees is still incomplete and needs a } \\
\text { lot of training }\end{array}$ & 0,08 & 2 & 0,16 \\
\hline 2 & Funding 30\% Owner, 30\% Bank, 40\% Other Investor & 0,06 & 2 & 0,12 \\
\hline 3 & $\begin{array}{l}\text { PTL is a Startup company, the trademark is not yet known by the manufacturing } \\
\text { industry }\end{array}$ & 0,1 & 1 & 0,1 \\
\hline 4 & PTL does not yet have a good enough network with Stakeholders & 0,08 & 1 & 0,08 \\
\hline 5 & $\begin{array}{l}\text { Although the location to be chosen is quite good, at the beginning of our business } \\
\text { we will only rent a shophouse, not buy it and this means it is not safe. }\end{array}$ & 0,06 & 2 & 0,12 \\
\hline & Total Score & 1 & & 2,79 \\
\hline
\end{tabular}
Source: Author, 2021.

Table 3. above shows that the total score is 3.05 slightly above the median value of 2.50. This means have a strong internal factor position. 
Table 4. PT PTL VRIO Analysis

\begin{tabular}{|l|l|l|l|l|}
\hline \multicolumn{1}{|c|}{ Items } & Value? (V) & Rare? (R) & Inimit able? (I) & Organized? (O) \\
\hline Testing Machine & Yes & Yes & No & Yes \\
\hline Tracking Testing Process & Yes & Yes & Yes & Yes \\
\hline Flexibility of Service & Yes & Yes & No & Yes \\
\hline Reliability of Testing Result & Yes & Yes & No & Yes \\
\hline
\end{tabular}

Based on the results of the analysis in table 4. the company has one competitive advantage, namely: (1) Tracking Testing Process. This must be maintained and continuously developed so that it becomes an unfair advantage for the company.

\section{Strategic Planning}

Strategic planning is prepared by setting objective at first. The objective of the PTL team is to build a provide mechanical testing services and solutions with the right business model, so that will be relate to value proposition canvas.

\section{a. Input Stage}

The EFE matrix is calculated based on the variables that have been determined previously in PEST analysis to understand how effective the company's current strategy is in responding to these factors. As for the IFE matrix is calculated based on the variables that have been determined previously in Internal analysis to determine which factors have a major influence on the company's business and vice versa which factors are the company's biggest weaknesses.

The Competitive Profile Matrix (CPM) identifies the company's main competitors and their strengths and weaknesses in relation to the strategic position of the company. Critical Success Factor is filled with a combination of analysis of demand and analysis of competition

Table 5. Critical Success Factor

\begin{tabular}{|c|c|c|c|c|c|c|c|c|c|c|}
\hline \multirow{2}{*}{ No } & \multirow{2}{*}{ Critical Success Factor } & \multirow{2}{*}{ Weight } & \multicolumn{2}{|c|}{ PTL } & \multicolumn{2}{|c|}{ BBKK } & \multicolumn{2}{|c|}{ Sucofindo } & \multicolumn{2}{|c|}{ Hi - Test } \\
\hline & & & Rating & Score & Rating & Score & Rating & Score & Rating & Score \\
\hline 1 & Test Machine & 0,08 & 3 & 0,24 & 4 & 0,32 & 2 & 0,16 & 4 & 0,32 \\
\hline 2 & Location & 0,1 & 4 & 0,4 & 2 & 0,2 & 4 & 0,4 & 2 & 0,2 \\
\hline 3 & Tracking System & 0,07 & 3 & 0,21 & 2 & 0,14 & 2 & 0,14 & 2 & 0,14 \\
\hline 4 & Service flexibility & 0,1 & 4 & 0,4 & 1 & 0,1 & 3 & 0,3 & 4 & 0,4 \\
\hline 5 & Price & 0,06 & 3 & 0,18 & 4 & 0,24 & 4 & 0,24 & 2 & 0,12 \\
\hline 6 & Test Variation & 0,08 & 4 & 0,32 & 2 & 0,16 & 3 & 0,24 & 2 & 0,16 \\
\hline 7 & Reliable Test Results & 0,07 & 4 & 0,28 & 3 & 0,21 & 2 & 0,14 & 4 & 0,28 \\
\hline 8 & Marketing and Sales & 0,06 & 3 & 0,18 & 2 & 0,12 & 3 & 0,18 & 3 & 0,18 \\
\hline 9 & HR & 0,08 & 2 & 0,16 & 3 & 0,24 & 4 & 0,32 & 4 & 0,32 \\
\hline 10 & Funding & 0,06 & 2 & 0,12 & 4 & 0,24 & 3 & 0,18 & 2 & 0,12 \\
\hline 11 & Trademark & 0,1 & 1 & 0,1 & 4 & 0,4 & 4 & 0,4 & 4 & 0,4 \\
\hline 12 & Stakeholder Relations & 0,08 & 1 & 0,08 & 4 & 0,32 & 4 & 0,32 & 3 & 0,24 \\
\hline 13 & Office / Building & 0,06 & 2 & 0,12 & 4 & 0,24 & 4 & 0,24 & 3 & 0,18 \\
\hline & Total & 1 & & 2,79 & & 2,93 & & 3,26 & & 3,06 \\
\hline
\end{tabular}

\section{b. Matching Stage}

\section{SWOT Matrix}

SWOT analysis is a systematic process of identifying various factors to determine the right formula and play the best role in the company's strategy (Ul Haq et al., 2020). Strategic planning needs to analyze the SWOT (strengths, weaknesses, opportunities, and threats) that exist in the company's current environment (David, 2016).

\section{IE Matrix}

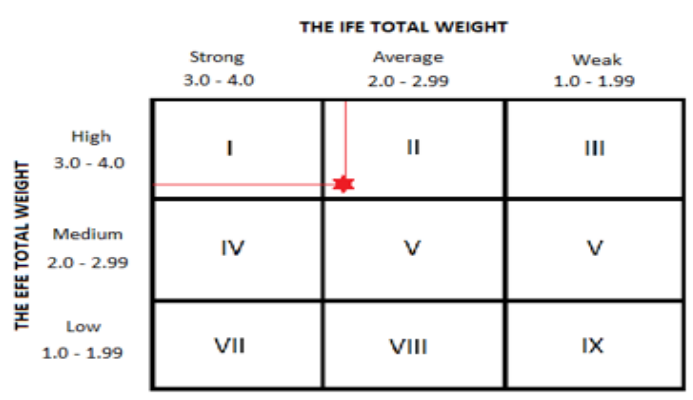

Figure 2. IE Matrix, Source: Author, 2021.

IE Matrix is one of the strategic management instruments to analyze the changing conditions and what strategic steps 
the company should take. IE matrix for PTL will fall in quadrant 2 which shows the company is in a position to grow and develop.

\section{c. Decision Stage QSPM}

After carrying out the input and matching stages, it is necessary to make a decision on what strategy will be chosen by PTL in running its business. The strategies chosen according to the results of IE and the Grand Strategy Matrix are product development and market penetration. For product development, we chose the strategy of opening a calibration lab in the short term, while for market penetration, we chose to add sales experienced by government tenders. The results of QSPM are shown in the table below.

\begin{tabular}{l} 
Table 6. The Order of the TAS Value \\
\begin{tabular}{|l|l|c|c|}
\hline No & Strategy Option & TAS Value & Priority \\
\hline 1 & Market Penetration Strategy & 6,46 & I \\
\hline 2 & Product Development Strategy & 4,24 & II \\
\hline
\end{tabular} \\
\hline
\end{tabular}

\section{Porter's Generic Strategies}

According to Porter, strategy allows organizations to increase their competitive level from three different bases, namely cost leadership, differentiation and focus. Porter calls it Generic Strategies. Cost leadership has 2 alternative types, namely Type 1 Low Cost Strategy, and Type 2, Best Value Strategy (Gide, 1967). PTL is included in the Type 3 category, differentiation. Where our main target is the manufacturing industry which is not too sensitive to the difference in test prices as long as the test results they have are reliable. In addition, the price that PTL offers will indeed be slightly more expensive than most competitors, especially government-owned test centers, but the services we provide more benefits than most competitors, so that customers will feel more value than the price offered.

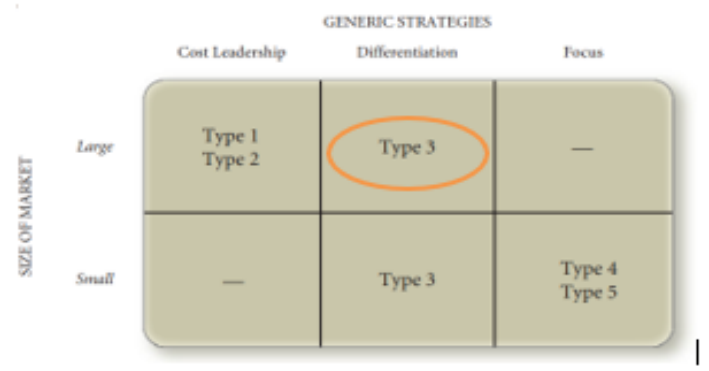

Figure 3. Generic Strategies, Source: Author, 2021.

\section{Lean Canvas Model}

Lean Canvas is a planning method that helps reach the core of a business idea. LMC puts everything important on one page, helping us define the key information we need, without unnecessary details. Lean Model Canvas is more suitable for startup businesses or businesses that are just being started, for that we choose LMC compared to BMC. Lean Model Canvas describes in detail the business model of PTL as shown below

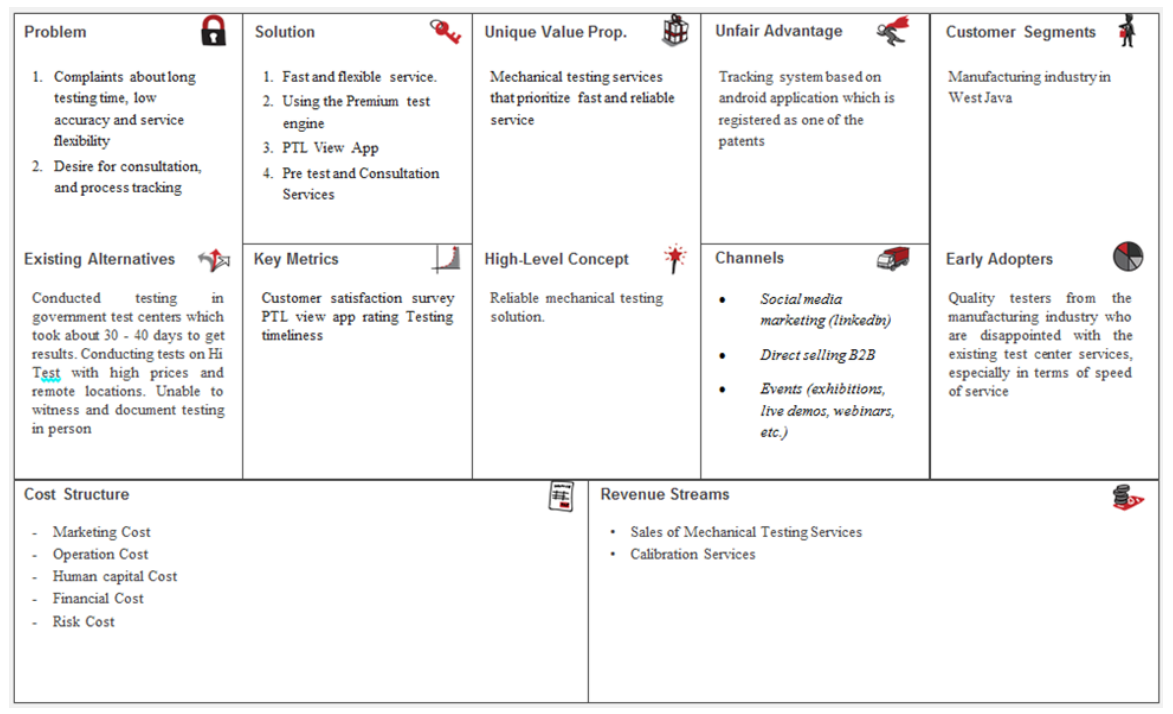

Figure 4. Lean Convas Model, Source: Author, 2021. 


\section{CONCLUSION}

Based on the results of the existing analysis, starting with determining the value proposition canvas, analyzing external and internal business factors, then proceed with matrix analysis of CPM, SWOT, IE, QSPM, and Porter's Generic Strategy, so this mechanical testing lab as startup company can be built properly. Eventually, the business activities carried out must be written on the lean business model canvas, so that the business will be competitive and sustainable. In addition, market penetration strategies and focus differentiation must continue to be evaluated and developed. Strategy formulation activities and evaluation of the lean business model canvas must be carried out regularly with include all the employee as one of the valuable resources.

\section{Acknowledgement: None}

\section{Conflict of Interest: None}

\section{Source of Funding: None}

\section{REFERENCES}

1. Akeem, A., \& Edwin, M. (2016). Vision and Mission in Organization: Myth or Heuristic Device? The International Journal of Business and Management, 4(3), 127134.

2. Anggit. et al., (2021). Implementation Of Operational Strategy Business In PT Maritim Industri Indonesia (MARINA). American International Journal of Business Management (AIJBM) Volume 4, Issue 08 (August- 2021), PP 178-183.

3. Candra, S. (2013). Aplikasi Model Lima Kekuatan Porter pada Restoran Drupadi. Binus Business Review, 4(1), 398-404. https://doi.org/10.21512/bbr.v4i1.1387

4. Choe, J. M. (2003). The effect of environmental uncertainty and strategic applications of IS on a firm's performance. Information and Management, 40(4), 257268. https://doi.org/10.1016/S0378-7206 (02)00008-3.

5. David, R. F. (2016). Managemen Strategik. Buku I, 12-30.
6. Dr. Alka Jain. (2015). SWOT Analysis in Thirukkural: Comparative Analysis with \nHumphrey SWOT Matrix\n. IOSR Journal of Business and Management (IOSR-JBM), 17(1), 31-34. https://doi.org/10.9790/487X-17123134

7. Gide, A. (1967). Understanding Michael Porter. In Angewandte Chemie International Edition, 6(11), 951-952.

8. Grant, R. M. (2010). SM Module Text Book: Contemporary Strategy Aalysis. In Concepts, Techniques, applications (Vol. 4).

9. Koumparoulis, D. N. (2013). PEST Analysis : The case of E-shop. International Journal of Economy, Management and Social Sciences, 2(February), 31-36.

10. Nisa, Puspita Chairun. Tamzil, Fachmi. (2021). Strategi Digital Business untuk UMKM. Jurnal Abdimas Volume 7 Nomor 4.

11. Nurlita, Lia. et al., (2021). Human Capital Implementation Strategy in the Marina Company. American International Journal of Business Management (AIJBM) Volume 4, Issue 08 (August-2021), PP 152-156

12. Osterwalder, A., Pigneur, Y., Bernarda, G., \& Smith, A. (2014). Value Proposition Design. New Jersey: John Wiley \& Sons, Inc.

13. Osterwalder, A. (2014). Value proposition design: how to create products and services customers want: get started with how to Create Products and Services Customers Want, 290.

14. Papulova, Z. (2014). The Significance of Vision and Mission Development for Enterprises in Slovak Republic. Journal of Economics, Business and Management, January 2014, 12-16. https://doi.org/10.7763/joebm.2014.v2.90

15. Pokorna, Balcarová \& Sergeeva. 2015. Value Proposition Canvas: Identification of Pains, Gains and Customer Jobs at Farmers' Markets. AGRIS online Papers in Economics and Informatics, 7(665-201645080), 123-130.

16. Porter, Michael E. 1990. The Competitive Advantage of Nations. The MacMillan Press Ltd. Prabangkara,

17. Setiyawati, E., Saputra, A., \& Indradewa, R. (2021). Strategic Formulation Analysis to Build a New Business Startup "Jamu Partnership" in Indonesia. International Journal of Research and Review, 8(8), 568576. https://doi.org/10.52403/ijrr.20210876 
18. U1 Haq, D., Indradewa, R., \& Author, C. (2020). Strategic Formulation Analysis of Virtual Gas Pipeline Business Development (CNG \& LNG). International Journal of Research and Review (Ijrrjournal.Com), 7(December), 12.

19. Umar. et al., (2018). Business Model Canvas As A Solution For Competing Strategy Of Small Business In Indonesia. International Journal of Entrepreneurship Volume 22, Issue 1.

20. Utami, Rachmawati Putri. et al., (2020). Implementation Marketing Strategy for Business Start- Up: Applications Home Care "4-Care." Journal of Multidisciplinary: Science, Engineering and Social Science Series Vol. 4, no. 1. ISSN/e-ISSN: 25410369/2613- 988X.
21. Ward, John., Peppard, Joe. (2002). Strategic Planning for Information System. Cranfield, Bedfordshire, United Kingdom: John Wiley $\&$ Sons, Ltd.

22. Widardi, Jodi. et al., (2019). Marketing Mix Strategy Implementation for Business Plan at LH Hotel. Journal of Multidisciplinary: Science, Engineering and Social Science Series Vol. 3, No. 5, 2019. ISSN/e-ISSN: 2541-0369/2513-988X.

How to cite this article: Subhan, Muhamad Elon, Farid Nur Iman et.al. Strategic formulation analysis to build a new mechanical testing laboratory in Indonesia. International Journal of Research and Review. 2022; 9(2): 288-296. DOI: https://doi.org/10.52403/ijrr. 20220239 